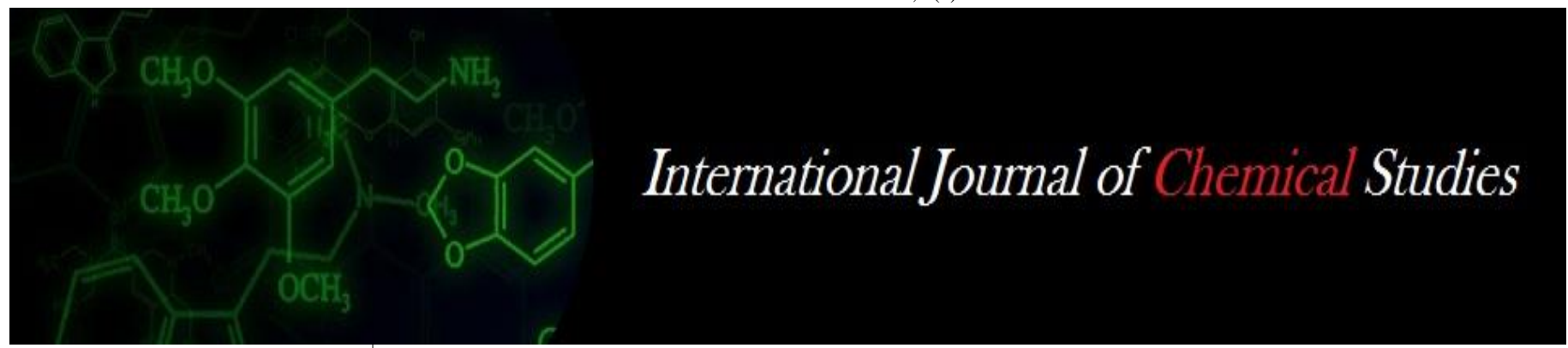

P-ISSN: 2349-8528

E-ISSN: 2321-4902

www.chemijournal.com

IJCS 2020; 8(6): 2168-2172

(C) 2020 IJCS

Received: 09-09-2020

Accepted: 21-10-2020

Harinder Singh

Department of Horticulture,

SAGR, Lovely Professional

University, Punjab, India

\section{Anis Mirza}

Department of Horticulture, SAGR, Lovely Professional

University, Punjab, India
Corresponding Author:

Anis Mirza

Department of Horticulture,

SAGR, Lovely Professional

University, Punjab, India

\section{Effect of plant growth regulators on growth, yield and quality of papaya (Carica papaya $\mathrm{L}$.) $\mathrm{Cv}$. Taiwan red lady}

\author{
Harinder Singh and Anis Mirza
}

DOI: https://doi.org/10.22271/chemi.2020.v8.i6ae.11096

\begin{abstract}
An experiment trail in field was carried out on research entitled 'Effect of plant growth regulators on growth, yield and quality in papaya (Carica papaya L.) cv. Taiwan Red Lady"' which was being held at V.P.O. Maheru, Tehsil Phagwara, District Kapurthala, Punjab under the Department of Horticulture, Lovely Professional University during the year 2019-20. Experimental trail was conducted by using various plant growth regulators $\mathrm{NAA}, \mathrm{GA}_{3}$, IAA at different concentrations in randomized block designed. The results showed that significantly higher growth parameters like plant height $(137.75 \mathrm{~cm})$, plant girth $(21.75 \mathrm{~cm})$, no. of leaves per plant (21) and chlorophyll index (56.43), yield $(14.92 \mathrm{~kg})$ and fruit parameters like fruit weight $(0.76 \mathrm{~kg})$, fruit length $(13.92 \mathrm{~cm})$ and diameter $(9.95 \mathrm{~cm})$ with application of $\mathrm{GA}_{3} 100 \mathrm{ppm}$. NAA $150 \mathrm{ppm}$ improved quality parameters such as TSS (14.22), acidity $(0.16 \%)$, ascorbic acid (70.22) and sugar content in fruit increased significantly.
\end{abstract}

Keywords: Papaya, plant growth regulators, growth, quality, yield

\section{Introduction}

Papaya is a tropical as well as subtropical fruit crop. Carica papaya Linn is the botanical name of the papaya and it belongs to family Caricaceae. Caricaceae have 48 species, only Carica papaya is the only edible fruit (Chadha, 1992) ${ }^{[9]}$. It is originated from Mexico and tropical America (Heywood et al., 2007) ${ }^{[13]}$. In $16^{\text {th }}$ century it was introduced to India from Malacca. It is grown in all over the world and India is the leading producer of papaya. It is grown mainly in Brazil, Mexico, Nigeria, Indonesia, Peru, China etc. In India papaya has overall area of 139 thousand hectare by a total annual production of 5831 thousand MT (NHB 2018-19). The leading producer of papaya in India is Gujarat which is followed by Andhra Pradesh and Karnataka. Papaya is one of the evergreen plants in nature which have softwood and hollow stem. It bears trifoliate leaves with long petioles. The height of papaya ranges up to $2.4 \mathrm{~m}$ and it can also withstand in low temperature and up to a height of $1500-2000 \mathrm{~m}$. There are three sex forms of papaya monoecious, dioecious and hermaphrodite (Arrilia et al., 1980) ${ }^{[3]}$. The fruit shape of female plant is short as compare to hermaphrodite plant. It has very fast growth it starts bearing after 8 months of transplanting. It is highly profitable crop.

Papaya is very refreshing and delicious fruit. Papaya is commonly recognised for having highly nutritive and medicinal value. It is highly valued for its digestive properties. Papaya has high amount of vitamin A \& C. In $100 \mathrm{gm}$. pulp of fruit it contains $9.81 \mathrm{~g}$ carbohydrates, $0.61 \%$ protein, $5.90 \%$ sugars, 39kcal energy, $61.8 \mathrm{mg}$ of vitamin C, vitamin A is 1094 IU (Bhgawat et al. 2011) ${ }^{[4]}$ because of its sweet taste it is freshly eaten and it has too much health benefits. Regular consumption of papaya can reduces the risk of heart disease, diabetes, cancer aiding in digestion.

To enhance the better growth and quality we use plant growth regulators in the fruit crops which are recommended. NAA shows significant part to increase fruit size and also control the pre-fruit drop in papaya. Gibberellic acid helps in plant growth and development and also helps in the fruit set, fruit weight, increase in length and girth (Suman et al., 2017) ${ }^{[29]}$. IAA plays vital role in plant development and growth with cell elongation and division, lateral root elongation and fruit development (Quint and Gray, 2006) ${ }^{[25]}$. Higher applications of IAA supports in the biosynthesis of ethylene, which plays a part in fruit softening and ripening 
(Pant et al., 2015) ${ }^{[21]}$. Endogenous contents of IAA benefits in the fruit setting and through initial growth developmental stages, after that IAA amounts have a tendency to decline before the ripening (Zaharah et al., 2012) ${ }^{[31]}$.

Papaya is being grown almost in all states of India. Although, production of papaya in the country as well as state is very high but export quality production is very low. There are number of constraints for export quality production of papaya such as lack of exportable varieties, lack of consistency and supply, large tracts of low and unproductive plantation, poor crop management, lack of knowledge about plant growth regulators and their suitable concentrations, heavy postharvest losses and all these factors also results for high cost of production. In modern production of fruit plant growth regulators shows significant role in developing quality and the production of fruits. Growth regulators have managed to succeed to increase plant yield and quality of many fruit plants. It can also put diverse effect when we use, so we should be certain of using growth regulators at proper time and getting maximum effect from it. The plant growth regulators are primarily focusing in plant growth, quality of fruit, helps in flowering and fruit setting and yield of fruit crops.

\section{Materials and Methods}

The present experimental study was being conducted at V.P.O. Maheru, Tehsil Phagwara, District Kapurthala, Punjab under the department of Horticulture, Lovely Professional University, Phagwara, Jalandhar, Punjab during the year 2019-20. The experimental plot was situated at latitude $-31^{\circ}$ $22^{\circ}$ and Longitude of $75^{\circ} 40^{\circ}$. The prevailing climatic conditions were typical i.e. extreme hot in summers and extreme cool in winters and the average rainfall is $686 \mathrm{~mm}$. The soil of research field is sandy loam in which available $\mathrm{N}$, $\mathrm{P}$ and $\mathrm{K}$ were $270 \mathrm{~kg} / \mathrm{ha}, 17 \mathrm{~kg} / \mathrm{ha}$ and $180 \mathrm{~kg} / \mathrm{ha}$ respectively. The soil was basic with $\mathrm{pH}$ of 7.9 .

Healthy and disease free seedlings of papaya cv. Taiwan Red Lady were brought from horticulture nursery of PAU, Ludhiana. The plants were planted at distance of $1.8 \times 1.8$ meter. Randomized block design was used in experiment with four replications and ten treatments. The ten treatments were as followed: $\mathrm{T}_{1}$-NAA $50 \mathrm{ppm}, \mathrm{T}_{2}$-NAA $100 \mathrm{ppm}, \mathrm{T}_{3}$-NAA $150 \mathrm{ppm}, \mathrm{T}_{4}-\mathrm{GA}_{3} 50 \mathrm{ppm}, \mathrm{T}_{5}-\mathrm{GA}_{3} 100 \mathrm{ppm}, \mathrm{T}_{6}-\mathrm{GA}_{3} 150$ ppm, T ${ }_{7}$-IAA $50 \mathrm{ppm}, \mathrm{T}_{8}$-IAA $100 \mathrm{ppm}, \mathrm{T}_{9}$-IAA $150 \mathrm{ppm}$, $\mathrm{T}_{10^{-}}$Control.

All the plants under the experiment block were fertilized uniformly with $200 \mathrm{~g} \mathrm{~N}+250 \mathrm{~g} \mathrm{P}+500 \mathrm{~g}$ K per plant during crop growth periods by localized placement method using Urea, DAP and MOP as fertilizer. FYM @ 15-20 kg is used as manure for filling the pits (Parmar et al., 2017). The required amount of plant growth regulators were prepared and applied at the interval of $45^{\text {th }}, 90^{\text {th }}$ and $135^{\text {th }}$ days of transplanting of papaya plants (Ali and Mazumdar, 1994). The required amount of NAA, GA 3 and IAA are dissolved in ethanol. By using distilled water the volume of solutions was made up to $1000 \mathrm{ml}$. The different concentration of solutions was sprayed carefully to wet the surface of leaf of whole plant. Excess wetting of leaves is avoided from the falling of solutions. Plants were randomly selected and tagged for observing plant growth parameters. Observation of yield and fruit parameters was done by standard methods and in each treatment ten fruits were selected. Sugars were determined by method given by Ranganna, $1986^{[26]}$. For determation of ascorbic acid we used 2, 6 Dichlorophenol-indophenol titration method which was given by Ranganna (1997) ${ }^{[27]}$.
Data was statistical analyzed by Gomez and Gomez (1984) [11]

\section{Results and Discussion \\ Effect of Plant growth regulators on vegetative growth of plants}

Plant growth regulators revealed some major variations on vegetative growth of plant under different treatments of the experiment trail as shown in Table 1. There is significant difference which was observed in plant growth after applying different growth regulators. From the various treatments $T_{5}$ $\left(\mathrm{GA}_{3} 100 \mathrm{ppm}\right)$ recorded maximum height of plant, plant girth and no. of leaves $(137.5 \mathrm{~cm}, 21.75 \mathrm{~cm}, 21$ respectively) and the minimum plant height was registered under $\mathrm{T}_{2}$ (NAA 100 ppm). The growth of plant increases might be due to the reason that $\mathrm{GA}_{3}$ helps in promoting the vegetative growth of plant by cell division. These plant height and plant girth related to the results of Bhogave and Raut $(2014)^{[5,6]}$ in papaya. Application of $\mathrm{GA}_{3}$ might increases number of leaves/ plant because $\mathrm{GA}_{3}$ at apical meristem helps in increasing system of nucleoprotein which is liable for leaf initiation and expansion. Similar results on no. of leaves/ plant were reported by Morales et al. (1999) ${ }^{[19]}$ and Mirza et al. (2019) in papaya.

The maximum plant spread (E-W, N-S), stalk length and chlorophyll index $(178.75 \mathrm{~cm}, 152.75 \mathrm{~cm}, 47 \mathrm{~cm}$ and 56.43 respectively) were recorded under superiority of treatment $\mathrm{T}_{5}$ $\left(\mathrm{GA}_{3} 100 \mathrm{ppm}\right)$, while the minimum $(101.5 \mathrm{~cm}, 103.5 \mathrm{~cm}$, $30.25 \mathrm{~cm}$ and 34.47) was recorded under $\mathrm{T}_{10}$ (Control). The maximum stalk length is due to $\mathrm{GA}_{3}$ helps to increase in cell division and elongation which increases stalk length. In conformity of this the data was similar to Hifny et al. (2017) [14]. The plant spread results from experiment are in closely related to research work of Prasad et al. (2012) ${ }^{[23]}$ and Hazarika et al. (2016) ${ }^{[12]}$ in papaya. The chlorophyll index results were similarly reported by Bhogave and Raut (2014) ${ }^{[5,}$ 6]. As far the days to early flowering and days to fruiting is concerned the treatment $\mathrm{T}_{5}\left(\mathrm{GA}_{3} 100 \mathrm{ppm}\right)$ treated plant comes to early flowering (125.5) and the minimum days to fruit set (215.75) is observed in treatment $\mathrm{T}_{3}$ (NAA $150 \mathrm{ppm}$ ), while the maximum days to flowering (131.75) and fruiting (225.25) were noticed in treatment $\mathrm{T}_{10}$ (Control). The experimental study of days to flowering is similar to Mitra and Ghanta (2000) ${ }^{[18]}$ in papaya. The study of days to fruit set was similar to research of Mir et al. (2004) ${ }^{[17]}$ in strawberry.

\section{Effect of plant growth regulators on yield parameters of plants}

In table 2 the effect of PGR's yield parameters is displayed. Maximum number of fruits, yield/plant $(18.37,14.92 \mathrm{~kg}$ ) were registered under $\mathrm{T}_{5}\left(\mathrm{GA}_{3} 100 \mathrm{ppm}\right)$ and minimum number of fruits and yield per plant $(9.5,8.02 \mathrm{~kg})$ was observed under treatment $\mathrm{T}_{10}$ (Control). The yield increases due to reason that $\mathrm{GA}_{3}$ helps in development of fruit by internal physiology which helps in supplying better nutrients and some other compounds that helps in growth and development of fruit properly, which increases fruit size and increase yield. The data obtained was similar to the data finding of Ghanta and Mitra (1998) ${ }^{[10]}$, Bhogave et al. (2015) ${ }^{[7]}$ in papaya. The results of number of fruits per plant were similar to research work of Hazarika et al. (2016) ${ }^{[12]}$ and Borana et al. (2018) ${ }^{[8]}$. Fruit length and fruit diameter (13.92 $\mathrm{cm}, 9.95 \mathrm{~cm}$,) were recorded maximum in treatment $\mathrm{T}_{5}\left(\mathrm{GA}_{3}\right.$ $100 \mathrm{ppm}$ ), and in treatment $\mathrm{T}_{10}$ (Control) it was recorded minimum. The carbohydrates level increases which help in 
increasing fruit length and cell division and cell elongation is stimulated by $\mathrm{GA}_{3}$ which increases length of fruit. Thus greater supply of photo assimilates in the fruit might have increased the fruit length. The plants which are treated with $\mathrm{GA}_{3}$ had increased girth of fruit as the semi permeability of cell wall is regulated by it. Mobilization of water is more amounts in the fruit which increases diameter of fruit. These results of fruit length and diameter were similar to research work of Vishwakarma et al. (2000) ${ }^{[30]}$ and Hazarika et al. (2016) ${ }^{[12]}$ in papaya.

Maximum fruit weight and fruit volume were recorded in treatment $\mathrm{T}_{5} \mathrm{GA}_{3} 100 \mathrm{ppm}(0.76 \mathrm{~kg}$ and $865.75 \mathrm{cc})$ and lowest in treatment $\mathrm{T}_{10}$ (Control). The $\mathrm{GA}_{3}$ helps in increasing fruit weight because its major function is elongation of cell. $\mathrm{GA}_{3}$ helps in increasing growth of vegetative parts of plant and which resulted in storing more food material for development of fruit and increases weight of fruit. These results are similar with Borana et al. (2018) ${ }^{[8]}$. Growth rate of cell increases by cell division and cell enlargement on physiological basis and helps in increasing fruit volume and an alteration in maturity of fruit. The result is in conformity with the earlier report by Hazarika et al. (2016) ${ }^{[12]}$ in papaya. Maximum pulp weight and pulp: peel ratio $(0.70 \mathrm{~kg}, 11.25)$ were noticed under the treatment $\mathrm{T}_{5}\left(\mathrm{GA}_{3} 100 \mathrm{ppm}\right)$. However the minimum pulp weight and was noticed under the treatment $\mathrm{T}_{7}$ (IAA $50 \mathrm{ppm}$ ) and the minimum pulp: peel ratio (9.45) was noticed under the control treatment $\left(T_{10}\right)$. The pulp weight increases due to reason that the size of fruit and weight of fruit was increased. Experimental results are similar to finding of Masalkar and Wavhal (1991) ${ }^{[16]}$ in ber and Bhogave et al. (2015) ${ }^{[7]}$ in papaya. The results obtained from pulp: peel ratio were similar to finding of Vishwakarma et al. (2000) [30] and Bhogave et al. (2015) [7] in papaya. The maximum peel weight $(0.06 \mathrm{~kg})$ recorded under $\mathrm{T}_{5}, \mathrm{~T}_{6}\left(\mathrm{GA}_{3}\right.$ 50 and $100 \mathrm{ppm})$ and while the minimum peel weight $(0.04$ $\mathrm{kg}$ ) was noticed in $\mathrm{T}_{7}$, (IAA $50 \mathrm{ppm}$ ). These results are similar with Bhogave et al. $(2014)^{[5,6]}$ in papaya.

\section{Effect of plant growth regulators on quality parameters of fruits}

The data related with quality characters of fruit is represented in the table 3 . The TSS percentage was maximum (14.22) under the treatment $\mathrm{T}_{3}$ (NAA $150 \mathrm{ppm}$ ) and the minimum TSS (10.05) was observed under $\mathrm{T}_{10}$ (Control). The TSS content of fruit increases due to that reason the plant growth regulators enhance the hydrolysis of polysaccharides into soluble solids and carbohydrate mobilization was increased from source to sink. Pusdekar and Pusdekar (2009) noticed the increase in TSS content of papaya fruit were most effective by NAA. Among the treatments significantly minimum acidity per cent $(0.16 \%)$ recorded under treatment $\mathrm{T}_{3}$ (NAA $150 \mathrm{ppm}$ ) and the highest acidity was recorded under $\mathrm{T}_{10}$ (Control). Acidity of papaya decreases because due to the fact that papaya is a climacteric fruit and acidity percentage decreases due to acids are converted into sugar and fruit consumed it as respiratory substrate throughout growth and development. Result of titratable acidity was similar to the result of Bhogave et al. (2015) ${ }^{[7]}$. A preview of data indicates that the papaya plants treated with $\mathrm{GA}_{3} 100$ ppm $\left(\mathrm{T}_{5}\right)$ recorded maximum ascorbic acid $(71.73 \mathrm{mg} / 100 \mathrm{~g})$, lowest ascorbic acid $(57.76 \mathrm{mg} / 100 \mathrm{~g})$ observed in control treatment $\left(\mathrm{T}_{10}\right)$, which showed significant differences among other treatments. The ascorbic acid increases when glucose-6phosphate is synthesised during the growth and development of fruit and the precursor of vitamin $\mathrm{C}$ is glucose-6-phosphate. The results were similar to results of Mitra and Ghanta (2000) ${ }^{[18]}$ in papaya.

The maximum total sugars and reducing sugars $(8.82,6.52)$ were registered under the treatment $\mathrm{T}_{3}$ (NAA $150 \mathrm{ppm}$ ). However, the minimum total sugars and reducing sugars were noticed under the treatment $\mathrm{T}_{10}$ (Control). The total sugar increases due to reason that carbohydrates present in fruit are mobilized and influenced by plant growth regulators and helps in increasing sugar content in fruit (Leopold, 1958). The data displayed was similar to the research work done by Anawal et al. (2015) ${ }^{[2]}$ in pomegranate. The reducing sugar increases due to reason starch is converted into sugar and ultimately observed the more total soluble solids under the application of Plant growth regulators. Experimental results were related to Anawal et al. (2015) ${ }^{[2]}$ in pomegranate. Nonreducing sugar $(2.03 \%)$ was recorded highest under treatment $\mathrm{T}_{5}\left(\mathrm{GA}_{3} 100 \mathrm{ppm}\right)$ and lowest non- reducing sugar $(1.43 \%)$ is observed in treatment $\mathrm{T}_{10}$ (Control). Sugar content might be increased because of metabolic activities which helps in degrading polysaccharides to sugars and convert organic acid to simple sugars. The observations are similar with the research work done by Singh et al. (1986) ${ }^{[28]}$ in mango

Table 1: Effect of plant growth regulators on vegetative growth of the papaya plants

\begin{tabular}{|c|c|c|c|c|c|c|c|c|c|}
\hline Treatment & $\begin{array}{c}\text { Plant height } \\
(\mathbf{c m})\end{array}$ & $\begin{array}{c}\text { Plant girth } \\
(\mathbf{c m})\end{array}$ & $\begin{array}{c}\text { No. of } \\
\text { leaves }\end{array}$ & $\begin{array}{c}\text { Plant spread } \\
\text { E-W }(\mathbf{c m})\end{array}$ & $\begin{array}{c}\text { Plant spread } \\
\text { N-S }(\mathbf{c m})\end{array}$ & $\begin{array}{c}\text { Stalk length } \\
(\mathbf{c m})\end{array}$ & $\begin{array}{c}\text { Chlorophyll } \\
\text { index }\end{array}$ & $\begin{array}{c}\text { Days to first } \\
\text { flowering }\end{array}$ & $\begin{array}{c}\text { Days to } \\
\text { fruit set }\end{array}$ \\
\hline $\mathrm{T}_{1}$ & 97.75 & 13.5 & 13 & 104.75 & 105.75 & 34.25 & 35.62 & 131.5 & 217.25 \\
\hline $\mathrm{T}_{2}$ & 88 & 13 & 13 & 105.25 & 105 & 36.25 & 35.4 & 127 & 211 \\
\hline $\mathrm{T}_{3}$ & 105.5 & 16 & 16 & 119.5 & 115.75 & 41 & 37.25 & 130 & 205.75 \\
\hline $\mathrm{T}_{4}$ & 120.5 & 20 & 18.5 & 112.25 & 115 & 41.25 & 43.35 & 129.5 & 224.25 \\
\hline $\mathrm{T}_{5}$ & 137.75 & 21.75 & 21 & 178.75 & 152.75 & 47 & 56.43 & 125.5 & 215.75 \\
\hline $\mathrm{T}_{6}$ & 133.25 & 21 & 18.5 & 149.5 & 141.5 & 42.75 & 51.1 & 128.5 & 216 \\
\hline $\mathrm{T}_{7}$ & 113.75 & 17.25 & 15.75 & 109.25 & 112.25 & 38.75 & 42.22 & 128 & 225 \\
\hline $\mathrm{T}_{8}$ & 102.25 & 14 & 14.25 & 134.25 & 131.75 & 35.25 & 34.47 & 129.75 & 220.5 \\
\hline $\mathrm{T}_{9}$ & 108.75 & 16.5 & 14 & 120.75 & 118.75 & 38.25 & 47.17 & 127.5 & 218.25 \\
\hline $\mathrm{T}_{10}$ & 99.5 & 14 & 13 & 101.5 & 103.5 & 30.25 & 34.47 & 131.75 & 225.25 \\
\hline C.D. $(\mathrm{P}=0.05)$ & 20.68 & 4.73 & 4.20 & 5.6 & 6.79 & 8.99 & 4.84 & 3.41 & 4.02 \\
\hline $\mathrm{SE}(\mathrm{m})$ & 7.089 & 1.62 & 1.44 & 1.92 & 2.33 & 3.08 & 1.66 & 1.17 & 1.38 \\
\hline
\end{tabular}


Table 2: Effect of plant growth regulators on yield attributing parameters of papaya plants

\begin{tabular}{|c|c|c|c|c|c|c|c|c|c|}
\hline Treatment & $\begin{array}{c}\text { No. of } \\
\text { fruits/plant }\end{array}$ & $\begin{array}{c}\text { Yield/ } \\
\text { plant(kg) }\end{array}$ & $\begin{array}{c}\text { Fruit length } \\
(\mathbf{c m})\end{array}$ & $\begin{array}{c}\text { Fruit diameter } \\
(\mathbf{c m})\end{array}$ & $\begin{array}{c}\text { Fruit weight } \\
(\mathbf{k g})\end{array}$ & $\begin{array}{c}\text { Fruit volume } \\
(\mathbf{c c})\end{array}$ & $\begin{array}{c}\text { Pulp weight } \\
(\mathbf{k g})\end{array}$ & $\begin{array}{c}\text { Peel weight } \\
(\mathbf{k g})\end{array}$ & $\begin{array}{c}\text { Pulp: Peel } \\
\text { ratio }\end{array}$ \\
\hline $\mathrm{T}_{1}$ & 11.5 & 8.87 & 12.3 & 8.12 & 0.58 & 632 & 0.53 & 0.05 & 9.89 \\
\hline $\mathrm{T}_{2}$ & 12.75 & 9.72 & 12.68 & 8.55 & 0.63 & 630.75 & 0.58 & 0.05 & 9.89 \\
\hline $\mathrm{T}_{3}$ & 14.37 & 11.25 & 13.17 & 8.92 & 0.62 & 672.5 & 0.57 & 0.05 & 10.63 \\
\hline $\mathrm{T}_{4}$ & 13.5 & 11.12 & 12.45 & 8.78 & 0.6 & 642 & 0.56 & 0.05 & 9.75 \\
\hline $\mathrm{T}_{5}$ & 18.37 & 14.92 & 13.92 & 9.95 & 0.76 & 865.75 & 0.7 & 0.06 & 11.25 \\
\hline $\mathrm{T}_{6}$ & 15.25 & 14.65 & 13.75 & 9.65 & 0.72 & 813.25 & 0.64 & 0.06 & 10.63 \\
\hline $\mathrm{T}_{7}$ & 11.25 & 8.37 & 12.8 & 7.8 & 0.54 & 582.5 & 0.5 & 0.04 & 9.84 \\
\hline $\mathrm{T}_{8}$ & 11.5 & 9.62 & 12.78 & 8.05 & 0.6 & 643.25 & 0.53 & 0.05 & 9.83 \\
\hline $\mathrm{T}_{9}$ & 13 & 10.17 & 13.25 & 8.42 & 0.67 & 693.25 & 0.61 & 0.05 & 10.85 \\
\hline $\mathrm{T}_{10}$ & 9.5 & 8.02 & 11.9 & 8.07 & 0.56 & 574.75 & 0.51 & 0.05 & 9.45 \\
\hline $\mathrm{C} . \mathrm{D} .(\mathrm{P}=0.05)$ & 1.46 & 1.09 & $\mathrm{~N} / \mathrm{A}$ & 0.73 & 0.08 & 7.38 & 0.08 & 0.01 & $\mathrm{~N} / \mathrm{A}$ \\
\hline $\mathrm{SE}(\mathrm{m})$ & 0.50 & 0.37 & 0.444 & 0.25 & 0.03 & 2.53 & 0.03 & 0.01 & 0.59 \\
\hline
\end{tabular}

Table 3: Effect of plant growth regulators on the quality parameters of papaya fruit

\begin{tabular}{|c|c|c|c|c|c|c|}
\hline Treatment & TSS $\left({ }^{\circ}\right.$ Brix $)$ & Acidity (\%) & Ascorbic acid (mg/100 g) & Total sugar (\%) & Reducing Sugar (\%) & Non reducing sugar $(\%)$ \\
\hline $\mathrm{T}_{1}$ & 10.75 & 0.21 & 62.66 & 8.02 & 6.24 & 1.78 \\
\hline $\mathrm{T}_{2}$ & 12.07 & 0.22 & 64.92 & 8.12 & 6.3 & 1.83 \\
\hline $\mathrm{T}_{3}$ & 14.22 & 0.16 & 70.22 & 8.52 & 6.82 & 1.7 \\
\hline $\mathrm{T}_{4}$ & 10.55 & 0.22 & 64.17 & 8.25 & 6.24 & 1.96 \\
\hline $\mathrm{T}_{5}$ & 12.57 & 0.18 & 71.73 & 8.31 & 6.27 & 2.03 \\
\hline $\mathrm{T}_{6}$ & 12.05 & 0.19 & 68.32 & 8.05 & 6.28 & 1.85 \\
\hline $\mathrm{T}_{7}$ & 10.55 & 0.24 & 58.87 & 7.96 & 6.47 & 1.48 \\
\hline $\mathrm{T}_{8}$ & 11.05 & 0.24 & 59.65 & 7.88 & 6.31 & 1.57 \\
\hline $\mathrm{T}_{9}$ & 11.87 & 0.21 & 64.17 & 8.29 & 6.21 & 1.91 \\
\hline $\mathrm{T}_{10}$ & 10.05 & 0.26 & 57.76 & 7.11 & 5.68 & 1.43 \\
\hline C.D. $(\mathrm{P}=0.05)$ & 1.05 & N/A & 5.43 & 0.4 & 0.53 & N/A \\
\hline $\mathrm{SE}(\mathrm{m})$ & 0.36 & 0.02 & 1.86 & 0.13 & 0.18 & 0.23 \\
\hline
\end{tabular}

\section{Conclusion}

From the results obtained during the research work we can conclude that plants treated with $\mathrm{GA}_{3} 100 \mathrm{ppm}$ have shown significant increase in the vegetative characters of plants at different stages of plant as well as on fruit yield. Plant treated with NAA $150 \mathrm{ppm}$ have shown increase in quality of fruits like TSS, Acidity, Ascorbic acid, Total sugar and reducing sugar. Basis on the present investigation, we can conclude that $\mathrm{GA}_{3} 100$ ppm when applied as foliar application it was founded as best treatment by which growth, yield of fruit is influenced.

\section{References}

1. Ali SL, Mazumdar BC. Effects of applications of plant growth regulators to papaya on the output and proteolytic activity of latex tapped from immature fruits, Journal of Horticultural Science 1994;69(5):805-807.

2. Anawal VV, Narayanaswamy P, Ekabote SD. Effects of plant growth regulators on fruit set and yield of pomegranate $\mathrm{cv}$. Bhagwa. International J. of Scientific Research 2015;4:2277-8179.

3. Arrilia MC, De JF, Mencha JF, Rolz C, Shaw PC. Tropical sub-tropical fruits. AVI. West part, connection, USA, 1980, 316-340.

4. Bhagwat S, Haytowitz DB, Holden JM. USDA database for the flavonoid content of selected foods, release 3. US Department of Agriculture: Beltsville, MD, USA 2011.

5. Bhogave AF, Raut UA. Studies on effect of plant growth regulators on vegetative growth and flowering of Papaya. Eco. Env. \& Cons. 2014;20:387-390.

6. Bhogave AF, Raut UA, Kharde RP. Effect of plant growth regulators on yield of papaya. Bioinfolet-A Quarterly J. of Life Sci 2014;11:119-121

7. Bhogave AF, Raut UA, Shinde GS. Influence of plant growth regulators on fruit quality of papaya (Carica papaya L.). Trends in Biosciences 2015;8(7):1736-1740.
8. Borana PD, Joshi PC, Verma P, Nandre BM, Bhadhuria HS, Joshi ND. Effect of plant growth regulators on yield and quality of pomegranate (Punica granatum L.) cv. Bhagwa. Green Farming 2018;9(1):165-168.

9. Chadha KL. Scenario of papaya production and utilization in India. Indian J. of Hort 1992;49(2):97-119.

10. Ghanta PK, Mitra SK. Effect of some chemicals on the performance of papaya (Carica papaya L.). Progressive Horti. 1998;30(1, 2):8-13.

11. Gomez KA, Gomez AA. Statistical procedures for Agricultural Research $2^{\text {nd }}$ Ed. John Willey and Sons, New York 1984.

12. Hazarika TK, Sangma BD, Mandal D, Nautiyal BP, Shukla AC. Effect of plant growth regulators on growth, yield and quality of tissue cultured papaya (Carica papaya L.) cv. Red Lady. Indian J Agri. Sci 2016;86(3):124-128

13. Heywood VH, Brummitt RK, Culham A, Seberg O. Flowering plant families of the world. Firefly Books 2007. ISBN 9781554072064.

14. Hifny HA, Khalifa SM, Hamdy AE, Abd El-Wahed AN. Effect of GA3 and NAA on Growth, Yield and Fruit Quality of Washington Navel Orange. Egypt. J Hort. 2017;44(1):33-43.

15. Leopold AC. Auxin uses in the control flowering and fruiting. Ann. Rev. plant Physiol 1958;9:281-301.

16. Masalkar SD, Wavhal KN. Effect of various growth regulators on physico-chemical properties of ber cv. Umran. Maharashtra J. of Horti 1991;5(2):37-40.

17. Mir MM, Barche S, Kirad KS, Singh DB. Studies on the response of plant growth regulators on growth, yield and quality of strawberry (Fragaria ananassa Duch) cv. Sweet Charley. Plant Archives 2004;4(2):331-333.

18. Mitra SK, Ghanta PK. Modification of sex expression in papaya (Carica papaya)Cv. Ranchi. Acta Hortic 2000; 515:281-286 DOI:10.17660/ActaHortic.2000.515. 
19. Morales PJP, Santos BM, Colon W. Effect of ethanol and gibberellic acid combinations on papaya (Carica papaya L.) seedling growth. Proceeding of the $35^{\text {th }}$ Annual Meeting, Caribbean Food Crops Society, Castries St. Lucia, 1999, 183-189.

20. National Horticulture Board. Area and production of Papaya. nhb.gov.in 2018-19.

21. Pant G, Prakash A, Pavani JVP, Bera S, Deviram GVNS, Kumar A, Prasuna RG. Production, optimization and partial purification of protease from Bacillus subtilis. Journal of Taibah University for Science 2015;9(1):5055.

22. Parmar P, Patil SJ, Kumar S, Chaudhari M, Tandel BM. Response of fertilizer application on growth of papaya var. Red lady. Int. J. Current Microbiology and Application Sciences 2017;6(12):2375-2379.

23. Prasad M, Minz M, Kumar R, Das B. Effect of mulching and PGRs on growth, yield and economics of strawberry (Fragaria ananassa Duch.) cv. Douglas. J of Interacademicia 2012;16(1):44-55.

24. Pusdekar GG, Pusdekar MG. Effect of plant growth regulators on flowering and fruit quality in papaya (Carica papaya L.) cv. CO-2. New Agriculturist, 2009;20 $(1,2): 107-110$

25. Quint M, Gray WM. Auxin signaling. Current Opinion in Plant Biology 2006;9(5)(Book).

26. Ranganna S. Hand Book of Analysis and Quality control for Fruit and Vegetable Product. Tata Mc-Graw Hill pub., New Delhi 1986.

27. Ranganna S. Hand Book of Analysis and Quality control for Fruit and Vegetable Product. Tata Mc-Graw Hill pub., New Delhi 1997.

28. Singh M, Chaudhary AS, Prasad M. A note on effect of some plant regulators on fruit retention in mango (Mangifera indica L.). Haryana J Hort. Sciences, 1986;15(3, 4):221-223.

29. Suman M, Sangma PD, Meghawal DR, Sahu OP. Effect of growth regulators on fruit crops. Journal of Pharmacognosy and Phytochemistry. 2017;6(2):331-337.

30. Vishwakarma SA, Sachan BP, Kumar A. Effect of 2, 4-D and GA3 on sex expression in papaya (Carica papaya L.). New Botanist 2000;27(1, 4):151-158.

31. Zaharah SS, Singh Z, Symons GS, Reid JB. Role of Brassinosteroids, Ethylene, Abscisic Acid and Indole-3Acetic Acid in Mango Fruit Ripening. Journal of Plant Growth Regulation 2012;31:363-372. 